The Impact of Audit Fees on Forward-Looking Disclosures in Integrated Reports Dr/ Eman Abdalla Mohammed Yousef

\title{
The Impact of Audit Fees on Forward-Looking Disclosures in Integrated Reports
}

Eman Abdalla Mohammed Yousef

\section{Abstract:}

This study examines the association between auditor's fees and the extent of forward-looking information disclosure in integrated reports. The study included a sample 52 non-financial firms whose reports are available on the International Integrated Reporting Council (IIRC) official website for the year 2017. The results indicate that auditor's fees are negatively associated with forwardlooking disclosure. While the study failed to a statistical significant association between the effectiveness of the internal control system and forward-looking information disclosure levels in integrated reports. This study contributes to the literature in determinants of forward-looking disclosures in integrated reports. Keywords: forward-looking disclosures; audit fees; internal control; integrated reports.

\section{Introduction:}

Investors needs of information had increased to exceed traditional historical information to include additional future related information to allow them make better investment decisions. Forward-looking financial and non-financial information provide users with a full picture of firm

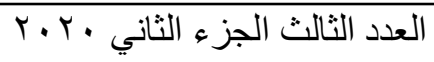

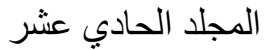


The Impact of Audit Fees on Forward-Looking Disclosures in Integrated Reports

Dr/ Eman Abdalla Mohammed Yousef

performance and the ability to create value which assist them in the decision-making process. The International Integrated Reporting Council (IIRC) in 2010 introduced the concept of Integrated Reporting (IR) as user-oriented report through which firms integrate forward-looking financial and non-financial information in one single report (Haji and Anifowose, 2016), that provides users full picture about firm performance and ability to create value through eyes of management (Cheng et al., 2014; Demartini and Trucco, 2017).

Forward-looking disclosures (FLD) are highly valued by information users as they present firms projections related to their plans, operations, performance and ability to create value leading to a reduction in investors inaccurate beliefs about firm future, decrease information asymmetry problems (Bozanic et al., 2014), increase transparency, improve investors ability to anticipate firm future earning (Al-Najjar and Abed, 2014), leading to appropriate investment decisions.

However, despite FLD importance, there is no conceptual framework for preparing and disclosing Forward-looking information (FLI) (Al-Najjar and Abed, 2014), which reduce firms incentives to disclose FLI to avoid possible litigations and reputation damages associated with false predictions (Hassanein and Hussainey, 2015), and due to FLI future nature which has high levels of uncertainties making it unverifiable or auditable at time of disclosure causing additional pressure on external

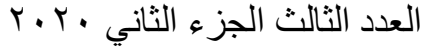

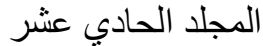


The Impact of Audit Fees on Forward-Looking Disclosures in Integrated Reports

Dr/ Eman Abdalla Mohammed Yousef

auditors (Zaky, 2015). So, to ensure the quality of audit work and avoid possible litigation risk, disciplinary penalties and reputation damage (Zaky, 2015), external auditor need to be independent from management control. An important proxy for auditor independence is auditor fees.

The remainder of the study is divided as follows. Section two discusses forward-looking information disclosure in annual reports. Section three represents literature review and hypotheses development. Section Four describes research design and results discussion. Section five concludes the paper.

\section{Forward-looking disclosures in integrated reports}

Integrated reporting is a principles-based approach that applies integrated thinking to provide users of corporate reports with a comprehensive view about how a firms operations, governance, and performance have led to value creation over short, medium and long term (Steyn, 2014; Camilleri, 2018; Dumay et al., 2018; Kılıç and Kuzey, 2018). Hence, integrated reporting helps to improve transparency, usefulness, and comparability of corporate disclosures and improve the firm's reputation and legitimacy (Ioana and Adriana, 2014; Steyn, 2014; Garanina and Dumay, 2017). This, in turn, enables users to make better investment decisions.

The IIRC's framework states six important principles that should be considered by management in preparing its annual

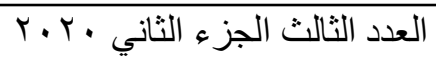

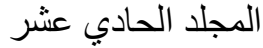


The Impact of Audit Fees on Forward-Looking Disclosures in Integrated Reports Dr/ Eman Abdalla Mohammed Yousef

integrated reports (IIRC, 2013; Demartini and Trucco, 2017). Strategic focus and future orientation is considered an important principle which stated that firms should include in their annual integrated reports forward-looking information disclosures related to their future objectives, how they will be achieved and challenges that could hinder their achievement, expectations related to the external environment, challenges and uncertainty related to future events (IIRC, 2013).

Forward-looking disclosures in integrated reports will assist investors in evaluating the firm's future performance, ability to create value (Menicucci, 2013, Bozanic, et al., 2014) and make better investment decisions (OSC, 2008; Leung, 2015; Kılıç and Kuzey, 2018; Abad and Bravo, 2018). However, forward-looking disclosures are highly uncertain and may differ significantly from actual results (Zaglol, 2004; Celik, et al., 2006), leading to potential litigation and reputation damage to the disclosing firms (Abdulrahman, 2010; PWC, 2013; Bozanic, et al., 2013; K1lıc and Kuzey, 2018). Therefore, the need for external auditors to reduce ambiguity associated with forwardlooking information disclosure has increased.

\section{Literature review and hypotheses development}

The dynamic and subjective nature of external audit quality makes it difficult to be measured directly and can be only evaluated by using proxies for audit quality. Audit Quality

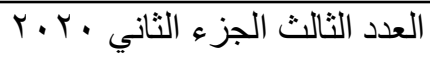$$
\text { المجلد الحادي عشر }
$$ 
The Impact of Audit Fees on Forward-Looking Disclosures in Integrated Reports

Dr/ Eman Abdalla Mohammed Yousef

Indicators (AQIs) work as incentives that help in improving audit process quality, increase investors' ability to assess the quality of audit work results, and help standard setters to view challenges and deficiencies facing audit profession (Martin, 2013). AQIs are driven from factors that exist that either exist inside the audit firm and are related to audit quality supply, or driven from factors that exist outside the audit firm and are related to audit quality demand (IAASB, 2014; Senjaya and Firnanti, 2017). Regarding AQIs that exist inside the audit firm and related to Audit quality supply is represented in the audit firm size, auditor independence, experience and qualification, industrial specialization, and reputation.

External auditor independence is an important indicator for audit quality, as it represents the assurance that external auditors are not familiar with the client in a way that could jeopardize auditor integrity (Tobi et al., 2016), and impair audit independent opinion causing litigations and reputation loss (Kaklar et al., 2012). Auditor fees are considered a good proxy for auditor independence.

Most of the prior studies that examined external audit process quality have focused on the associations between external audit quality and financial reporting quality. In this context, Philip (2008) examined the role of audit quality on annual report disclosures for 150 Australian listed firms. The

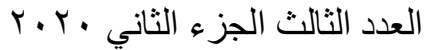

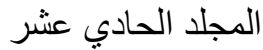


The Impact of Audit Fees on Forward-Looking Disclosures in Integrated Reports Dr/ Eman Abdalla Mohammed Yousef

results indicated that corporations audited by high-quality auditors have more and higher-quality disclosures. Kaklar et al. (2012) also found that external audit quality impacts positively financial reporting. Nwanyanwa (2017) also examined the influence of audit quality, measured by external auditor independence and financial reporting for Nigerian firms and documented the existence of a significant positive association between audit quality and financial reporting reliability. Mohamed et al. (2018) also found a negative association between total fees and external audit quality.

Few studies examined the association between audit quality and integrated reporting. Al-Najjar and Abed (2014) reported a positive association between corporate governance quality and levels of forward-looking disclosures in annual reports to stockholders. Bravo (2016) found that firms preferred to disclose forward-looking information to reduce stock return volatility and uncertainty related to firm future. Opferkuch (2018) showed that forward-looking disclosures reduce information asymmetry and improve firm valuation in the capital market. However, none of the prior studies had examined the association between external audit quality and forward-looking information disclosed in integrated reports that applied the IIRC ${ }^{\mathrm{ee}} \mathrm{s}$ principles.

$$
\text { r. r. العدد الثالث الجزء الثاني }
$$

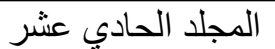


The Impact of Audit Fees on Forward-Looking Disclosures in Integrated Reports Dr/ Eman Abdalla Mohammed Yousef

Oprisor (2015) argued that it is difficult to obtain a reasonable level of assurance regarding information disclosed in annual integrated reports due to the lack of regulations related to integrated reports audit and key performance indicators related to non-financial and forward-looking information disclosed in integrated reports. They suggested the need for setting guidelines for audit methodology for integrated reporting. Goicoechea et al. (2019) indicated that there are concerns about the credibility of integrated reporting due to the lack of audit regulation regarding integrated reporting.

Auditor fees: Corporations' main motive to engage external auditors is due to their independence which adds credibility to disclosed information and gains stakeholders' confidence (Mohammed et al., 2018). Independent auditors are more capable of expressing their own professional opinion about the fair presentation of the client's financial statements without any pressure from the client that could jeopardize their integrity (Kaklar et al., 2012; Tobi et al., 2016). So, auditor independence can be used to evaluate audit quality (Salehi and Kangarlouei, 2010; Tobi et al., 2016). Auditor independence can be measured through auditor fees (DeFond and Zhang, 2014).

Total fees present total fees paid by the client to audit firms for all the services provided. Fees may differ from one client to another and from one engagement to another for the

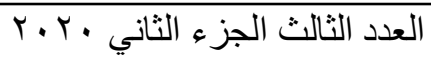

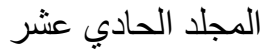


The Impact of Audit Fees on Forward-Looking Disclosures in Integrated Reports Dr/ Eman Abdalla Mohammed Yousef

same client (Oladipupo and Monye-Emina, 2016; Abdul-Rahman et al., 2017). Clients may use fees to pressure the auditors to act in their favor (DeFond and Zhang, 2014). Fees paid by the clients may make the auditors economically dependent on their clients (Hoitash et al., 2007), which compromises auditor independence and impair audit quality (Oladipupo and Monye-Emina, 2016), leading to less informative disclosure (Nwanyanwa, 2017), and low reporting quality (Kinney and Libby, 2002; Al-Khaddash et al., 2013; Coulton et al., 2014).

Hoitash et al. (2007) and Ettredge et al. (2013) indicated the existence of a negative association between total fees and audit quality as fees pressure lead to a reduction in audit quality. Mohammed et al. (2018) examined the association between audit fees and audit quality for a sample of Nigerian petroleum firms from 2007-2014. Their results indicated that audit fees are negatively associated with audit quality, as high audit fees can compromise audit independence, which results in a decline in audit quality.

While most prior studies reported a significantly negative relationship between auditor fees and audit quality. Oladipupo and Monye-Emina (2016) found an insignificant association between audit fees and audit quality. Kamolsakulchai (2015) also found no correlation between audit fees, audit firm size and financial reporting quality. However, Yuniarti (2011), Tobi et al.

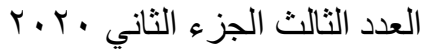

المجلد الحادي عشر 
The Impact of Audit Fees on Forward-Looking Disclosures in Integrated Reports Dr/ Eman Abdalla Mohammed Yousef

(2016), and Abdul-Rahman et al. (2017) found a positive association between audit fees and audit quality, as high fees could encourage auditor to assign more experienced audit staff and do more work, leading to higher audit quality.

Given the conceptual arguments and empirical evidence in most prior studies, total fees are considered a good indicator for audit quality as they include all fees paid by client to audit firm for both audit and non-audit services which are proxy for auditor independency. Thus, we expect to find a negative association between total fees paid to auditor and audit quality, resulting in lower levels of disclosures including forward-looking disclosures in integrated reports. Thus, we present the following hypothesis (stated in the alternative form):

H1. Auditor fees are negatively associated with the extent of forward-looking disclosure in integrated reports.

Internal control effectiveness: The management ability to fulfill financial reporting requirements depends mainly on the effectiveness of internal controls in reducing the risk of material misstatements (ICFR, 2019), protecting firm assets, ensuring data accuracy and transparency (Zhang et al., 2007; Shanszadeh and Zolfaghari, 2015), and improving reporting quality (Al-Khaddash et al., 2013). Agyei-Mensah (2016) stated that internal control effectiveness helps improve disclosure quality and information

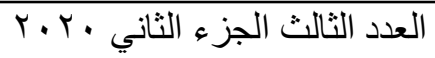

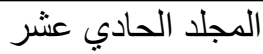


The Impact of Audit Fees on Forward-Looking Disclosures in Integrated Reports Dr/ Eman Abdalla Mohammed Yousef

transparency. Augustine et al. (2013) reported that the internal control system significantly impacts audit work quality.

Shanszadeh and Zolfaghari (2015) surveyed 104 Iranian auditors to identify and determine the impact of internal control effectiveness on the audit process quality. Results indicated that internal control effectiveness enhances audit quality through increasing the detection of significant errors and distortions, resulting in more credible reports. Based on the discussions above, we suggest that an effective internal control system helps improve the firm's financial reporting and result in a greater amount of forward-looking information disclosure in integrated reports and formulate the following hypothesis (stated in the alternative form):

H2. The effectiveness of the internal control system is positively associated with the extent of forward-looking information disclosure in integrated reports.

\section{Research Design}

\subsection{Sample and data}

The initial sample includes the 90 non-financial firms with integrated reports available on the Integrated Reporting Examples Database accessible on the IIRC website for the year 2017. We did not include firms operating in financial services and utilities due to significant differences in their financial 
The Impact of Audit Fees on Forward-Looking Disclosures in Integrated Reports Dr/ Eman Abdalla Mohammed Yousef

reporting practices. Then, 38 firms had been dropped as they did not disclose information about auditor fees, which is used in this study as a proxy for auditor independence. The final sample consists of hand-collected data for 52 non-financial firms from Europe (46 percent), South Africa (33 percent), Asia ( 9 percent), Australasia (6 percent), North America (4 percent), and South America ( 2 percent) region. These firms operate in different industries such as basic materials (46 percent), consumer goods (19 percent), consumer services (13 percent), health care (12 percent), and technology (10 percent).

\subsection{Dependent variable}

In investigating the association between auditor fees an indicator for audit quality and the extent of forward-looking disclosures in annual integrated reports, we used a forwardlooking information disclosure index constructed by manual content analysis of forward-looking information disclosed by non-financial firms in their integrated reports. The manual content analysis used in the study is similar to the method employed by Kent and Ung (2003), Uyar and Kilic (2012), Bravo (2016), Menicucci and Paolucci (2017), and K1lıç and Kuzey (2018) in their studies on various issues related to forwardlooking information disclosed in integrated reports. The forwardlooking disclosure index divided total forward-looking information disclosures into 15 items related to advertising and

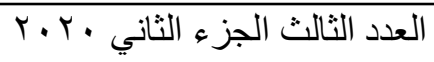

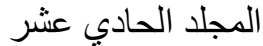


The Impact of Audit Fees on Forward-Looking Disclosures in Integrated Reports Dr/ Eman Abdalla Mohammed Yousef

publicity plans, capital expenditure plans, expected cash flows, earning targets, financial risks, growth opportunities, industry or market risks, investment projects, expected market share, political risks, planned product research, and development, expected profitability, sales target, share price, and environmental risks

\subsection{Test variables}

The quality of external audit has been evaluated through using auditor fees and effectiveness of the internal control system. Auditor fees (AF) was measured as the natural log of total fees paid to the audit firm scaled by the nature log of firm size. Internal control system effectiveness (IC) was coded 1 if the firm maintains an effective internal control system and 0 otherwise.

\subsection{Control variables}

the researcher had controlled the effect of remaining firm qualitative features represented in the board of directors' independence and gender diversity, and firm quantitative features represented in firm size, profitability and leverage on the levels of FLD in annual IRs to be able to measure the impact of auditor fees, and effectiveness of internal control systems on FLI disclosed in firm annual IRs. The board of directors' independence (BODIND) represented the percentage of

$$
\begin{aligned}
& \text { العدد الثالث الجزء الثاني •r.r. } \\
& \text { المجلد الحادي عشر }
\end{aligned}
$$


The Impact of Audit Fees on Forward-Looking Disclosures in Integrated Reports Dr/ Eman Abdalla Mohammed Yousef

independent directors among the board. According to AgyeiMensah (2019) and Mustafa et al. (2018) study results, independent board members tend to provide external pressure to enhance firm performance, lower levels of financial reporting problems, and increase disclosure levels.

The board of directors' gender diversity (BODGEN) was given a scale of 1 if more than half of board members are female and 0 otherwise. According to code of best practice of corporate governance 5th edition for the year (2016), the existence of female directors among the board helps to promote involvement, information sharing, and enhance shelf-worth among the board as female directors are more interested in building relationships with their subordinates and apply transformational approach which impacts firm performance (Abdullah and Ismail, 2016) and helps to apply more oversight on management actions leading to better disclosure (Srinidhi et al., 2011).

Firm size (FSIZE) measured through the natural log of the firm total assets book value in US dollars. Agyei-Mensah (2019) study stated that large-size firms tend to have high reporting and audit quality as they have more resources, exposed to more public scrutiny and can afford costs associated with additional disclosure compared with small-size firms. Firm profitability measured using Return on Asset Ratio (ROA) represented in the ratio net income after tax to firm total assets. Philip's (2008)

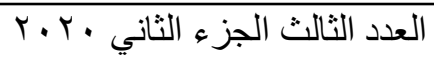

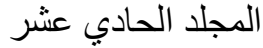


The Impact of Audit Fees on Forward-Looking Disclosures in Integrated Reports Dr/ Eman Abdalla Mohammed Yousef

study indicated that firm profitability and disclosure level are positively associated. And Agyei-Mensah's (2019) study reported that firms with good performance tend through disclosing more information compared with corporations with poor performance.

And Leverage (LEVE) measured through the ratio of total liabilities to total assets. According to Aljifri and Hussainey (2007) and Kwame's (2017) studies, empirical results stated that high-leverage firms have to disclose more information to satisfy the creditor's needs of information which impact disclosure levels positively. So, the researcher controlled the effect of the board of director's independence, gender diversity, firm size, profitability, and leverage on the levels of FLD in annual IRs.

\section{Results and discussions}

\subsection{Descriptive statistics}

Table 1 presents the descriptive statistics for the dependent, test and control variables. The extent of FLI disclosed in the IRs ranges from 8 items to 29 items with an average of about 17 items. The nature log of the auditor fees ranges between -0.5411 and 0.3175 , with an average of 0.0564 . The average of internal control effectiveness is 0.79 ; indicating 79 percent of the sample firms maintained an effective internal control system.

$$
\text { المجلد الحادي عشر }
$$


The Impact of Audit Fees on Forward-Looking Disclosures in Integrated Reports Dr/ Eman Abdalla Mohammed Yousef

\section{Table 1}

\section{Descriptive Statistics Results}

\begin{tabular}{|c|c|c|c|c|c|}
\hline Variables & Mean & Median & $\begin{array}{c}\text { St. } \\
\text { Deviation }\end{array}$ & $\begin{array}{c}\text { Minimu } \\
\mathrm{m}\end{array}$ & $\begin{array}{c}\text { Maximu } \\
\mathrm{m}\end{array}$ \\
\hline $\begin{array}{c}\text { Total forward-looking } \\
\text { information }\end{array}$ & 17.04 & 17.50 & 5.099 & 8 & 29 \\
\hline Total auditor fees & -3.497 & -3.448 & 0.6319 & -5.10 & -1.89 \\
\hline Internal control effectiveness & 0.79 & 1 & 0.412 & 0 & 1 \\
\hline $\begin{array}{c}\text { Board of directors } \\
\text { independence }\end{array}$ & $51.09 \%$ & $50 \%$ & $19.84 \%$ & $23.1 \%$ & $100 \%$ \\
\hline $\begin{array}{c}\text { Board of director gender } \\
\text { diversity }\end{array}$ & 0.48 & 0.00 & 0.505 & 0 & 1 \\
\hline Firm size & 3.8369 & 3.8848 & 0.94235 & 1.81 & 6.03 \\
\hline Firm profitability & 0.5697 & 0.4980 & 0.71232 & -0.164 & 0.267 \\
\hline Firm leverage & 0.51269 & 0.47500 & 0.20714 & 0.050 & 1.270 \\
\hline While the & 0 & directors & & & \\
\hline
\end{tabular}

While the board of directors' independence ranges between 0.231 and 1 with a mean 0.511 and standard deviation of 0.198 . The average of the board of directors' gender diversity and internal control system effectiveness are 0.48 and 0.79 respectively. The firm size natural $\log$ is 3.8369 million US dollars ranging between 1.81 and 6.03 million US dollars and profitability range between -0.164 and 0.267 with mean 0.05697 , while leverage means is 0.513 with a standard deviation of 0.207 and ranges between 0.05 and 1.27.

\subsection{Spearman and Pearson Correlation Coefficient}

The researcher conducted a Spearman and Pearson Correlation Coefficient to determine the strength of the

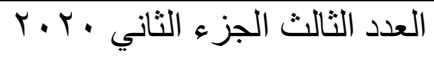


The Impact of Audit Fees on Forward-Looking Disclosures in Integrated Reports Dr/ Eman Abdalla Mohammed Yousef

association between the dependent and test variables. Table IV had shown the results of Spearman and Pearson Correlation Coefficient Analysis for the study variables.

\section{Table 2}

\section{Spearman and Pearson Correlation Coefficient}

\begin{tabular}{|c|c|c|c|c|c|c|c|c|}
\hline Variables & $\mathbf{1}$ & $\mathbf{2}$ & $\mathbf{3}$ & $\mathbf{4}$ & $\mathbf{5}$ & $\mathbf{6}$ & $\mathbf{7}$ & $\mathbf{8}$ \\
\hline Total FLD & 1 & .057 & $.335^{*}$ & -.045 & .088 & .236 & -.184 & -.087 \\
\hline Auditor Fees & -.235 & .171 & -.007 & .055 & .177 & $-.699^{* *}$ & -.013 & .070 \\
\hline BOD Ind. & $.335^{*}$ & $-.289^{*}$ & 1 & .180 & .163 & .262 & -.200 & -.043 \\
\hline BOD Gender & -.045 & .135 & .180 & 1 & .216 & .038 & .062 & $.299^{*}$ \\
\hline Internal Control & .088 & -.073 & .163 & .216 & 1 & -.030 & -.083 & .014 \\
\hline Firm Size & .236 & -.243 & .262 & .038 & -.030 & 1 & .101 & .065 \\
\hline Profitability & -.184 & .158 & -.200 & .062 & -.083 & .101 & 1 & .019 \\
\hline Leverage & -.087 & -.128 & -.043 & $.299^{*}$ & .014 & 0.65 & .019 & 1 \\
\hline
\end{tabular}

** Correlation is significant at 0.01 levels (2-tailed)

* Correlation is significant at 0.05 levels (2-tailed)

Note: The Spearman correlations are presented in the upper right half, while the Pearson correlations are presented in the lowerleft half.

The results of both Spearman and Pearson Correlation Coefficient Analysis indicated that the board of director independence had a positive significant impact on Total FLD $(\mathrm{r}=0.342, \mathrm{P}<0.05)$. While the board of directors' independence and firm size had a positive significant impact on quantitative FLD $(r=0.339, \quad \mathrm{P}<0.05)$ and $(\mathrm{r}=0.498, \mathrm{p}<0.01)$ respectively. However, all other test variables have no significant impact on any of the study dependent variables

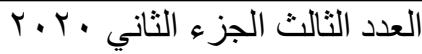

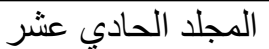


The Impact of Audit Fees on Forward-Looking Disclosures in Integrated Reports Dr/ Eman Abdalla Mohammed Yousef

\subsection{Ordinary Least Square (OLS) Regression Analysis}

The researcher applied the Ordinary Least Square (OLS) Regression Analysis for regression models to test the study hypothesis and determine the association between dependent and test variables.

$$
\begin{aligned}
& \mathrm{FLI}=\beta 0+\beta 1 \mathrm{AF}+\beta 2 \mathrm{IC}+\beta 3 \mathrm{BODIND}+\beta 4 \mathrm{BODGEN}+ \\
& \beta 5 \mathrm{FSIZE}+\beta 6 \mathrm{ROA}+\beta 7 \mathrm{LEVE}+\varepsilon .
\end{aligned}
$$

\section{Model Summary}

\begin{tabular}{|l|r|r|r|rr|}
\hline Model & \multicolumn{1}{|c|}{$\mathrm{R}$} & R Square & \multicolumn{1}{c|}{$\begin{array}{c}\text { Adjusted R } \\
\text { Square }\end{array}$} & \multicolumn{2}{|c|}{$\begin{array}{c}\text { Std. The error of the } \\
\text { Estimate }\end{array}$} \\
\hline 1 & $.623^{\mathrm{a}}$ & .388 & .200 & \\
\hline
\end{tabular}

ANOVA

\begin{tabular}{|l|r|r|r|r|r|}
\hline Model & \multicolumn{1}{|c|}{$\begin{array}{c}\text { Sum of } \\
\text { Squares }\end{array}$} & \multicolumn{1}{c|}{ df } & $\begin{array}{c}\text { Mean } \\
\text { Square }\end{array}$ & F & \multicolumn{2}{|c|}{ Sig. } \\
\hline 1 Regressio & 514.364 & 12 & 42.864 & 2.060 & $.044^{\mathrm{b}}$ \\
$\mathrm{n}$ & 811.559 & 39 & 20.809 & & \\
$\quad \begin{aligned} \text { Residual } \\
\text { Total }\end{aligned}$ & 1325.923 & 51 & & & \\
\hline
\end{tabular}

a. Dependent Variable: total FLI

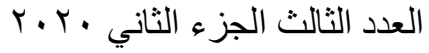

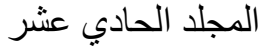


The Impact of Audit Fees on Forward-Looking Disclosures in Integrated Reports Dr/ Eman Abdalla Mohammed Yousef

Coefficients

\begin{tabular}{|c|c|c|c|c|c|c|}
\hline \multirow{2}{*}{\multicolumn{2}{|c|}{ Model }} & \multicolumn{2}{|c|}{$\begin{array}{l}\text { Unstandardized } \\
\text { Coefficients }\end{array}$} & \multirow{2}{*}{$\begin{array}{c}\text { Standardized } \\
\text { Coefficients }\end{array}$} & \multirow[b]{2}{*}{$\mathrm{t}$} & \multirow[b]{2}{*}{ Sig. } \\
\hline & & B & Std. Error & & & \\
\hline \multirow[t]{8}{*}{1} & (Constant) & -15.072 & 9.026 & & -1.670 & .103 \\
\hline & Auditor fees & -2.777 & 1.566 & -.344 & -1.773 & .042 \\
\hline & $\begin{array}{l}\text { Board of directors } \\
\text { independence }\end{array}$ & 10.578 & 4.384 & .412 & 2.413 & .021 \\
\hline & $\begin{array}{l}\text { Board of directors gender } \\
\text { diversity }\end{array}$ & -2.948 & 1.531 & -.292 & -1.925 & .062 \\
\hline & $\begin{array}{l}\text { Internal control system } \\
\text { effectiveness }\end{array}$ & 1.081 & 1.707 & .087 & .633 & .530 \\
\hline & Firm size & -.001 & 1.089 & .000 & -.001 & .999 \\
\hline & Profitability & -5.210 & 9.768 & -.073 & -.533 & .597 \\
\hline & Leverage & 1.593 & 3.483 & .065 & .457 & .650 \\
\hline
\end{tabular}

a. Dependent Variable: total FLI

\subsection{Discussion of Regression Analysis Results}

According to OLS regression analysis results; only four out of six hypotheses had been accepted, mean the remaining two hypotheses had been rejected. Regarding the audit firm size (AS), results indicate the existence of a statistically significant positive association between audit firm size an indicator for external audit process quality and Total FLD, Quantitative FLD and Qualitative FLD in annual IRs $(\beta=12.717, \mathrm{P}<0.05),(\beta=5.413, \mathrm{P}<0.10)$

$$
\text { العدد الثالث الجزء الثاني • r r r }
$$$$
\text { المجلد الحادي عشر }
$$ 
The Impact of Audit Fees on Forward-Looking Disclosures in Integrated Reports Dr/ Eman Abdalla Mohammed Yousef

and $(\beta=7.304, \mathrm{P}<0.10)$ respectively. Thus $\mathrm{H} 1$ had been accepted.

Such results were consistent with Wang et al. (2008), Philip (2008), Al-Ajmi (2009), Francis and Yu (2009), AlKhaddash et al. (2013), and Achyarsyah and Molina (2014) study empirical results. According to Wang et al. (2011) audit firm size affects corporation disclosure levels positively, Philip (2008) encourages high levels of informativeness disclosure, and AlAjmi (2009) leads to more credible financial reporting and better audit quality. Big4 audit firms are more concerned with protecting their reputational capital and avoid possible litigation risks, and they have more resources and expertise to detect material misstatements in client annual reports more quickly and more accurately compared with Non-big4 audit firms which will result to better audit quality and high levels of FLD in annual IRs. Meanwhile, the study failed to find association between the effectiveness of internal control system and FLD.

\section{Conclusion}

In response to users' need for information, corporations have increased the amount of information, especially forwardlooking information, disclosed in different reports to assist users in evaluating firm performance and ability to create value to make better investment decisions (Leung, 2015). Furthermore, firms started to adopt the integrated reporting approach that

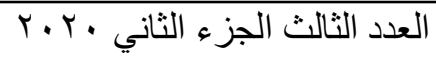

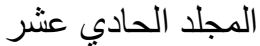


The Impact of Audit Fees on Forward-Looking Disclosures in Integrated Reports Dr/ Eman Abdalla Mohammed Yousef

integrates historical and forward-looking information, both financial and non-financial, in one single report to provide users with a holistic view about firm performance (IIRC, 2013). However, forward-looking information disclosures have been criticized due to their future nature. Therefore, there exists the need for external authority independent of management to assess forward-looking information disclosure (DeFond and Zhang, 2014).

the findings also indicate that auditor fees and the level of forward-looking information disclosure are negatively associated. Higher fees may impair auditor independence and thus impact audit quality negatively, resulting in less forward-looking information disclosure in integrated reports. While, failed to find an association between the internal control system and forwardlooking information disclosure in integrated reports.

The study makes several made contributions to accounting disclosure literature by providing empirical evidence on the determinants of forward-looking information disclosure in integrated reports. To the best of our knowledge, this is the first study that investigates the association between external audit quality and the extent of forward-looking information disclosure in integrated reports. Specifically, the study provides first empirical evidence on the associations between auditor fees and

$$
\text { r. r. العدد الثالث الجزء الثاني }
$$

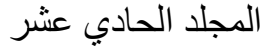


The Impact of Audit Fees on Forward-Looking Disclosures in Integrated Reports Dr/ Eman Abdalla Mohammed Yousef

the effectiveness of the internal control system and the extent of forward-looking information disclosure in integrated reports.

Moreover, prior forward-looking disclosure studies tended to focus on financial information, while this study investigates factors associated with the extent of both financial and nonfinancial forward-looking information in integrated reports. Finally, this study contributes to the emerging integrated reporting literature.

The study has some limitations. First, the study sample is relatively small because of relatively few companies, as available on the IIRC website, have adopted the integrated reporting concept. Also, many firms adopting integrated reporting are dropped because other requisite data are not available and/or the need to be hand-collected. Second, the study examines the extent of forward-looking information disclosure in non-financial firms integrated reports for only the year 2017 as data on forwardlooking disclosures need to be hand-collected. Third, the study examines the determinants related to audit quality of forwardlooking disclosure in integrated reports. Future research may examine the consequences of such forward-looking disclosures.

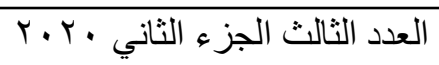


The Impact of Audit Fees on Forward-Looking Disclosures in Integrated Reports Dr/ Eman Abdalla Mohammed Yousef

\section{References :}

Abad, C. and Bravo, F. (2018) "Audit committee accounting expertise and forward-looking disclosures: A study of the US companies", Management Research Review, Vol. 41 No. 2, pp. 166-185.

Zaglol, G., (2004), "The responsibility of auditing of future accounting estimates in the light of Egyptian and International auditing standards", Unpublished paper, Faculty of Commerce, Tanta University, Egypt, pp. 1-57.

Abdullah, S., and Ismail, K. (2016) "Women directors, family ownership and earnings management in Malaysia", Asian Review of Accounting, Vol. 24 No. 4, pp. 525-550.

Abdul-Rahman, O., Benjamin, A. and Olayinka, O. (2017), "Effect of audit fees on audit quality: evidence from Cement Manufacturing Companies in Nigeria", European Journal of Accounting, Auditing and Finance Research, Vol.5 No.1, pp. 6-17.

Agyei-Mensah, B. (2019), "The effect of audit committee effectiveness and audit quality on corporate voluntary disclosure quality", African Journal of Economic and Management Studies, Vol. 10, No. 1, pp. 17-31.

Aljifri, K. and Hussainey, K. (2007), "The determinants of forwardlooking information in annual reports of UAE companies", Managerial Auditing Journal, Vol. 22 No. 9, pp. 881-894.

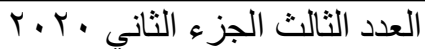

المجلد الحادي عشر 
The Impact of Audit Fees on Forward-Looking Disclosures in Integrated Reports Dr/ Eman Abdalla Mohammed Yousef

Al-Ajmi, J. (2009), "Audit firm, corporate governance, and audit quality: Evidence from Bahrain", Advances in Accounting, Incorporating Advances in International Accounting, Vol. 25 No. 1, pp. 64-74.

Al-Khaddash, H., Al-Nawas, R. and Ramadan, A. (2013) "Factors affecting the quality of auditing: The case of Jordanian Commercial Banks” International Journal of Business and Social Science, Vol. 4 No. 11, pp. 206-222.

Al-Najjar, B. and Abed, S. (2014), "The association between disclosure of forward-looking information and corporate governance mechanisms: Evidence from the UK before the financial crisis period", Managerial Auditing Journal, Vol. 29 No. 7 , pp. $578-595$.

Augustine, O., Mgbame, C., Sadiq, O. and Francis, A. (2013), "Internal control system and quality of audit work", Research Journal of Finance and Accounting, Vol.4 No.13, pp. 100-106.

Bravo, F. (2016), "Forward-looking disclosure and corporate reputation as a mechanism to reduce stock return volatility", Spanish Accounting Review, Vol. 19 No. 1, pp. 122-131.

Bozanic, Z., Roulstone, D., and Van, A. (2014), "Attributes of informative disclosures", Preliminary Version, Fisher College of Business, The Ohio State University, Columbus, pp. 1-56.

Camilleri, M. (2018), "Theoretical insights on integrated reporting: the inclusion of non-financial capitals in corporate disclosures". Corporate Communications: An International Journal, Vol. 23 No. 4, pp. 567-581.

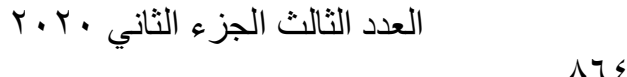$$
\text { المجلد الحادي عشر }
$$ 
The Impact of Audit Fees on Forward-Looking Disclosures in Integrated Reports Dr/ Eman Abdalla Mohammed Yousef

Celik, O., Ecer, A., and Karabacak, H. (2006), "Disclosure of forwardlooking information: evidence from listed companies on Istanbul Stock Exchange (ISE)", Investment Management and Financial Innovations, Vol. 3 No. 2, pp. 197-215.

Abdulrahman, W. (2010), "A suggested framework for forward-looking statement audit", Scientific Journal of Research and Business Studies, Vol. 3, pp. 13-46.

Cheng, M., Green, W., Conradie, P., Konishi, N. and Romi, A. (2014), “The international integrated framework: key issues and future research opportunities", Journal of International Financial Management and Accounting, Vol., 25 No. 1, pp. 90-119..

Coulton, J., Livne, G. and Taylor, S. (2014), "Investments in auditing and the quality of financial reporting", Working Paper, School of Accounting University of Technology, Stephen.Taylor@uts.edu.au.

Defond M., and Zhang, J. (2014), "A review of archival auditing research", Journal of Accounting and Economics, Vol. 85 No. 2, pp. 113-127.

Demartini, C. and Trucco, S. (2016), "Does intellectual capital disclosure matter for audit risk? Evidence from the UK and Italy", Sustainability, Vol. 8 No. 9, pp. 867.

Dumay, J., Torre, M., Bernardi, C. and Guthrie, J. (2018), "Integrated reporting and integrating thinking: practical challenges", Book Chapter, Challenges in Managing Sustainable Business: Reporting, Taxation, Ethics and Governance, Critical Integrated Reporting Research Project, pp. 1-27.

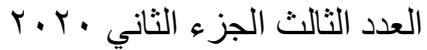

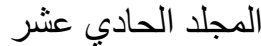


The Impact of Audit Fees on Forward-Looking Disclosures in Integrated Reports Dr/ Eman Abdalla Mohammed Yousef

Ettredge, M., Chan, L. and Elizabeth, E. (2013), "Fee pressure and audit quality", Accounting, Organizations and Society, Vol. 39 No. 4, pp. 247-263.

Garanina, T., and Dumay, J. (2017) "Forward-looking intellectual capital disclosure in IPOs: Implications for intellectual capital and integrated reporting", Journal of Intellectual Capital, Vol. 18 No. 1, pp. 128-148.

Goicoechea, E., Gómez-Bezares, F. and Ugarte, J. (2019), "Integrated reporting assurance: perceptions of auditors and users in Spain", Sustainability, Vol. 11, www.mdpi.com/journal/sustainability.

Haji, A. and Anifowose, M. (2016), "Audit committee and integrated reporting practice: Does internal assurance matter?", Managerial Auditing Journal, Vol. 31 No. 8/9, pp. 915-948.

Hassanein, A., and Hussainey, K. (2015), "Is forward-looking financial disclosure really informative? evidence from UK narrative statements", International Review of Financial Analysis, Vol. 41, pp. 52-61.

Zaky, A. (2015), "New trends in audit 2 under changing world", Suez Canal University Ismailia, Faculty of Commerce, pp. 364-370.

Hoitash, R., Markelevich, A. and Barragato, C. (2007), "Auditor fees and audit quality”, Managerial Auditing Journal, Vol. 22 No. 8, pp. 761-786.

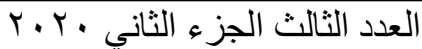

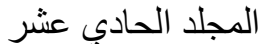


The Impact of Audit Fees on Forward-Looking Disclosures in Integrated Reports Dr/ Eman Abdalla Mohammed Yousef

IAASB, (2014), "Framework for audit quality key elements that create an environment for audit quality", The International Auditing and Assurance Standards Board (IAASB), www.iaasb.org.

ICFR, (2019), "Guide to internal control over financial reporting", Center for audit quality, https://www.thecaq.org/guide-internal-controlover-financial-reporting/.

IIRC, (2013), "The International integrated reporting (IR) framework", The International Integrated Reporting Council (IIRC), www.theiirc.org.

Ioana, D. and Adriana, T. (2014), "Research agenda on integrated reporting: new emergent theory and practice", Procedia Economic and Finance, Vol. 15, pp. 221-227.

Kaklar, H., Kangarlouei, S. and Motavassel, M. (2012), “Audit quality and financial reporting quality: case of Tehran stock exchange (TSE)", Innovative Journal of Business and Management, Vol. 1 No. 3, pp. 43-47.

Kamolsakulchai, M. (2015), "The impact of the audit committee effectiveness and audit quality on financial reporting quality of listed company in stocks exchange of Thailand", Review of Integrative Business \& Economics Research, Vol. 4 No. 2, pp. 328-341.

Kent, P. and Ung, K. (2003), "Voluntary disclosure of forward-looking earnings information in Australia", Australia Journal of Management, Vol. 28 No. 3, pp. 273-285

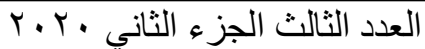

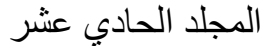


The Impact of Audit Fees on Forward-Looking Disclosures in Integrated Reports Dr/ Eman Abdalla Mohammed Yousef

Kılıç, M. and Kuzey, C. (2018), "Determinants of forward-looking disclosures in integrated reporting", Managerial Auditing Journal, Vol. 33 No. 1, pp. 115-144.

Kinney, W. and Libby, R. (2002) "Discussion of the relation between auditors fees for no audit services and earnings management", The Accounting Review, Vol. 77, pp. 107-114.

Kwame, B. (2017), "The relationship between corporate governance, corruption, and forward-looking information disclosure: a comparative study", Corporate Governance: The International Journal of Business in Society, Vol.17 No. 2, pp. 284-304.

Leung, E. (2015), "The effect of supplier relationships on disclosures of forward-looking information", Working Paper, Erasmus School of Economics, Erasmus University Rotterdam, pp.1-56.

Martin, R. (2013), "Audit quality indicators: Audit practice meets audit research", Current Issues in Auditing: American Accounting Association, Vol. 7 No. 2, pp. 17-23.

Menicucci, E. and Paolucci, G. (2017), "The determinants of forwardlooking information in integrated reporting: an empirical investigation in Europe", Proceedings of 12th Annual London Business Research Conference July 2017, Imperial College, London, UK, pp. 1-24.

Menicucci, E. (2013), "Firm characteristics and forward-looking information in management commentaries of Italian listed companies", African Journal of Business Management, Academic Journals, Vol. 7 No. 17, pp. 1667-1974.

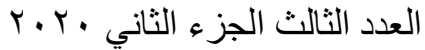

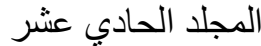


The Impact of Audit Fees on Forward-Looking Disclosures in Integrated Reports Dr/ Eman Abdalla Mohammed Yousef

Mohammed, A., Joshua, O. and Ahmed, M. (2018), “Audit fees and audit quality: a study of listed companies in the Downstream Sector of Nigerian Petroleum Industry", Humanities and Social Sciences Letters, Vol. 6 No. 2, pp. 59-73.

Mustafa, A. Che-Ahmad, A. and Chandren, S. (2018), "Board diversity, audit committee characteristics, and audit quality: the Moderating Role of the control-ownership wedge", Business and Economic Horizons, Vol. 14 No. 3, pp. 587-614.

Nwanyanwa, L. (2017), "Audit quality practices and financial reporting in Nigeria", International Journal of Academic Research in Accounting, Finance and Management Sciences, Vol. 7 No. 2, pp. 145-155.

Mohamed, S. (2016), "The impact of firm characteristics and governance efficiency on zFaculty of Commerce, Ain-Shams University, Egypt, Vol. 2, pp. 1-44.

Kinney, A. and Monye-Emina, H. (2016), "Do abnormal audit fees matter in Nigerian audit market?", International Journal of Business and Finance Management Research, Vol. 4 No. 6, pp. 64-73.

Oprisor, T. (2015), “Auditing integrated reports: are there solutions to this puzzle?", Procedia Economics and Finance, Vol. 25, pp. 87-95.

Opferkuch, J. (2018), "The information content of managers' forwardlooking disclosures", Working Paper, Goethe-University Frankfurt am Main, pp. 1-40.

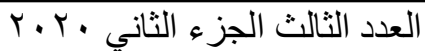

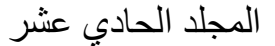


The Impact of Audit Fees on Forward-Looking Disclosures in Integrated Reports Dr/ Eman Abdalla Mohammed Yousef

OSC, (2008), “ "Defense for misrepresentations in forward-looking information", OSC Policy 51-604, Rules and Policies, pp. 1-10.

Philip D. (2008) "Audit quality and financial reporting disclosure", Working Paper, Flinders Business School, Flinders University, Adelaide, Australia, pp. 1-29.

PwC, (2013), "Guide to forward-looking information: Don't fear the future: communicating with confidence", PricewaterhouseCoopers LLP, pp. (1-31).

Salehi, M. and Kangarlouei, S. (2010), "An investigation of the effect of audit quality on accrual reliability of listed companies on Tehran stock exchange", Review of International Comparative Management, Vol. 11 No. 5, pp. 940-960.

Senjaya, M., and Firnanti, F. (2017), "Auditor characteristics, audit tenure, audit fee, and audit quality", Global Journal of Business and Social Science Review, Vol. 5 No. 3, pp. 94-99.

Shanszadeh, B. and Zolfaghari, N. (2015), "Impact of efficacious internal control on audit process: Auditors perspective", Review of Contemporary Business Research, Vol. 4 No. 2, pp. 97-107.

Srinidhi, B., Gul, F. and Tsui, J. (2011), "Female directors and earnings quality", Contemporary Accounting Research, Vol. 28 No. 5, pp. 1610-1644.

Steyn, M. (2014), "Benefit and Implementation Challenges of Mandatory Integrated Reporting: Perspectives of senior executives at South

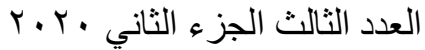

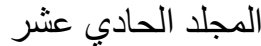

$\wedge \vee$. 
The Impact of Audit Fees on Forward-Looking Disclosures in Integrated Reports Dr/ Eman Abdalla Mohammed Yousef

African Listed Companies", Sustainability Accounting, Management, and Policy Journal, Vol. 5 No.4, pp. 476-503.

Tobi, B., Osasrere, A. and Emmanuel, U. (2016), “Auditor's independence and audit quality: a study of selected deposit money banks in Nigeria", International Journal of Finance and Accounting, Vol. 5 No. 1, pp. 13-21.

Uyar, A., Kilic, M. (2012), "Influence of corporate attributes on forwardlooking information disclosure in publicly traded Turkish corporations", Procedia - Social and Behavioral Sciences, Vol. 62 , pp. $244-252$.

Wang, Z., Lin, Z., and Liu, M., (2011), "Signaling efficiency of forwarding-looking information under IFRS", International Conference on Financial Management and Economics IPEDR, IACSIT Press, Singapore, Vol. 11, pp. 291-296.

Yuniarti, R. (2011), “Audit firms size, audit fee, and audit quality”, Journal of Global Management, Vol. 2 No. 1, pp. 84-97.

Zhang, Y., Zhou, J. and Zhou, N. (2007), “Audit committee quality, auditor independence, and internal control weaknesses", Journal of Accounting and Public Policy, Vol. 26 No. 3, pp. 300-327.

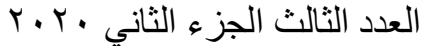

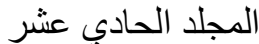

